\title{
Differential Aphid Colony Establishment in Dolichos Iablab Varieties Correlated with Some Plant Specific Factors That Impact on Aphid Fecundity
}

\author{
Hossain Ali Mondal ${ }^{*}$, Suvendu Kumar Roy', Lakshmi Hijam¹, Moumita Chakraborty ${ }^{1}$, \\ Puspendu Dutta ${ }^{2}$, Tapan Kumar Hath ${ }^{3}$
}

\begin{abstract}
${ }^{1}$ Department of Genetics and Plant Breeding, Uttar Banga Krishi Viswavidyalaya, Cooch Behar, India
${ }^{2}$ Department of Seed Science and Technology, Uttar Banga Krishi Viswavidyalaya, Cooch Behar, India

${ }^{3}$ Department of Agricultural Entomology, Uttar Banga Krishi Viswavidyalaya, Cooch Behar, India

Email: *hossainalimondal@gmail.com
\end{abstract}

How to cite this paper: Mondal, H.A., Roy, S.K., Hijam, L., Chakraborty, M., Dutta, P. and Hath, T.K. (2017) Differential Aphid Colony Establishment in Dolichos lablab Varieties Correlated with Some Plant Specific Factors That Impact on Aphid Fecundity. American Journal of Plant Sciences, 8, 754-769.

https://doi.org/10.4236/ajps.2017.84053

Received: September 23, 2016

Accepted: March 26, 2017

Published: March 29, 2017

Copyright (c) 2017 by authors and Scientific Research Publishing Inc. This work is licensed under the Creative Commons Attribution International License (CC BY 4.0).

http://creativecommons.org/licenses/by/4.0/

\begin{abstract}
Aphid establishes colony in the selective plant parts like vine, leaf petiole, leaflet, inflorescence, and tender fruit in Dolichos lablab Linn but not the entire plant. In this study, the aphid colony establishment in vine is focused to understand the differential resistance response between two varieties. At the early stage of aphid infestation, the aphid colony establishment was significantly different between two genotypes ( $\mathrm{p}$ value $=0.00)$ and abbreviated as "resistant" variety that supported lower aphid proliferation (mean value = $48.2 \pm 2.2$ ) and "susceptible" variety that supported comparatively higher aphid proliferation (mean value $=215.5 \pm 16.9$ ). The total aphid number was significantly different between the two varieties, realized at the early infestation stage when both "antixenosis" and "antibiosis" defense mechanisms were working on. Some plant specific factors like vine diameter, wet/ dry weight ratio of vine, phloem sap pressure, the compactness of the vine, wet/dry weight ratio of leaflet, length of leaf petiole, diameter of leaflet vein were identified as modulating factors. The impact of resistant variety on aphid was also investigated for better understanding of aphid defense mechanism.
\end{abstract}

\section{Keywords}

Dolichos lablab, Aphid Colony, Differential Vine Diameter, Differential Wet/Dry Weight Ratio of Vine, Differential Phloem Pressure, Differential Compactness of the Vine, Differential Aphid Fecundity, Differential Water Content in Aphid 


\section{Introduction}

Dolichos lablab Linn, newly renamed as Lablab purpureus (L) is herbaceous in nature, climbing type of growth habit, annual or perennial (for a short period of time) and possesses vigorous taproot. In the erect type, its thick stem can grow up to 3 feet, and the climbing type can grow up to $25 \mathrm{ft}$ [1]. Botanically, it has trifoliate and long-stemmed leaves. Each egg-shaped leaflet widens in the middle and is $7.5-15 \mathrm{~cm}$ long. The flowers are positioned in plant in clusters on an un-branched inflorescence in the angle between the leaf and the main stem. The petal color may be white, blue, or purple flowers depending on variety. Seedpods are $4-5 \mathrm{~cm}$ to $10 \mathrm{~cm}$ long [1] [2], smooth, flat, pointed, and contain 2 to 4 seeds. Seeds can be white, cream, pale brown, dark brown, red, black, or mottled depending on variety.

Dolichos lablab L. is grown as both pulse and vegetable crop. As a pulse crop (crop harvested for dry seed), it is cultivated in Africa, Asia, and the Caribbean. The green pod is consumed for vegetable purpose. Dolichos lablab is also used as forage, hay, and silage purpose. This crop is also recognized as forage crop. The leaf is very palatable in nature but the stem is not. The seeds are moderately palatable. Overall, it is one of the most palatable legumes for animals [1]. The leaf protein content varies from $21 \%$ to $38 \%$ and the seed protein profile varies from $20 \%$ to $28 \%$ crude protein [2]. The leaves are excellent hay for cattle and goats. Dolichos lablab is also recognized as a nitrogen-fixing green manure crop to improve soil quality. It produces more dry matter than cowpea (Vigna unguiculata) during drought weather and can contribute around $1750 \mathrm{lb}$ of leaf matter [2] or 2.5 tons of total biomass per acre [1]. Each ton of biomass again also produces $50 \mathrm{lb}$ of nitrogen [1]. Its initial growth in some agroclimatic zone may be slow, but once established, it competes well with weeds. It has an extensive root system that again improves the physical condition as well as function of the soil. In the United States, Dolichos lablab is used as an ornamental plant especially in the cut flower industry [3]. It was reported that up to 55 cut stems per plant could be done depending on the weather condition [4]. Dolichos lablab is an old world food crop that is thought to have originated in Africa [2] or India [5]. Dolichos lablab can be grown in a variety of soils, from sandy to clay type of soils and in a $\mathrm{pH}$ range of $4.5-7.5$ [2]. It performs very poor in saline or poorly-drained soils, but it grows better than most legumes under acidic conditions [1]. It can grow in drought or shady conditions, and will grow in areas with an average annual rainfall is 25 - 120 in [2]. It is more drought resistant than other similar legumes like common beans (Phaseolus vulgaris) and cowpea [6].

The main limiting problem in Dolichos lablab is that it is highly infested by aphid and consequently there is no fruitful harvest in favourable environmental condition. Aphid infestation is a major problem in many crops like Mustard, Bringal, Cotton, Cowpea etc. It was reported that a number of aphids (Hemiptera: Aphididae) are agriculturally important pests in a number of agricultural as well as horticultural crops. A number of disease causing viruses are also vectored by aphids in many crops like Cotton, Okra, Tomato and Chili etc. Aphid proli- 
ferates very quickly within very short period of time to achieve the population size above the economic threshold level. Aphid is exclusively phloem sap feeder. The mouth part of aphid is composed of the slender stylet and is very suitable for tapping the nutrient rich sieve element sap [7]. It is reported that the navigation of aphid stylet follows a predominantly intercellular route to minimize the cell damage that reduces the plant defense response on their way to reach the sieve element cell in the vascular tissue [8].

Saliva is secreted during the aphid stylet navigation towards the sieve element and plays a vital role in successful penetration [9] [10]. The first type of saliva is known as gel saliva and another type is also known as watery saliva [11]. The gelling saliva is proteinaceous in nature and encases the stylet after solidifying. This saliva is also known as sheath saliva and minimizes the physiological contact that reduces the induction of the plant defense response. After successful intercellular probing, the aphid secretes watery saliva into the host cell [8]. In this stage, switching from gel salivation to non-gelling (watery) salivation occurs into the penetrated cell or sieve element [12] [13]. It is well documented that the watery saliva contains various enzymes like pectinases, cellulases, polyphenol oxidases, peroxidases, and lipases [11] [14]. These enzymes have a role in establishing successful stylet penetration and subsequent prolong phloem sap feeding [15].

High pressure is maintained in the vascular system in the higher plant. The vascular sap is rich in sugar and protein which makes it an attractive target by pathogens including aphid. Plant has effective mechanism to minimize the loss of sieve element sap. Stylet penetration causes the turgor shift and pressure loss [16]. The induced turgor shift accumulates intra sieve element calcium ion as well as changes the redox state. The higher accumulated $\mathrm{Ca}^{++}$ion as well as turgor pressure shift are sensed by plant cell machinery which rapidly plugs the sieve pores to avoid the loss of sieve-tube sap [17]. The process is known as "Sieve-tube occlusion" which is regarded as instant phloem based plant defense in response to aphid attack [18]. The protein involved in sieve tube occlusion is well characterized. In Fabaceae family, the protein known as P-protein is responsible for sieve tube occlusion in a very fast way. This mechanism is universal in plants of Fabaceae family. Being a member of Fabaceae family, Dolichos lablab has sieve element occlusion mechanism. The phloem specific proteins (P-proteins) based occlusion occurs in some seconds in the Fabaceae family plants. The insoluble form of the P-proteins in sieve element present in the form like amorphous, granular, fibrillar, filamentous, tubular, and crystalline [19], but the type of form is dependent on plant species [20]. It was well reported in $V$. faba that utilizes the "forisome dispersion" mechanisms (P-protein based occlusion) to avoid the phloem sap immediately. Therefore, plant evolved very fast mechanism with immediate effect that plays a universal safety design module [21]. In the present study, two popular varieties of Dolichos lablab were considered for aphid resistance study. Aphid colony establishment in vine was focused for better understanding the resistance mechanism between the two varieties. Both varieties 
are popular in West Bengal but one is more susceptible as compared to the other. In the present research, some plant specific parameters were considered for the differential response to aphid colony establishment especially in vine region.

\section{Result and Discussion}

\subsection{Genotype Abbreviation and Description}

The genotypes selected for aphid colony establishment had different characteristic features which are presented in Supplementary Figure 1. The flower petal colour of one genotype was pink and abbreviated as "susceptible" genotype in this manuscript and the white/light cream colour petal was the characteristic feature of "resistant" genotype (Supplementary Figure 1(a)). The flatten fruit which was considered as vegetable is higher in length as well as breath (Supplementary Figure 1(b)). The pale green color was the characteristic feature of susceptible variety as compared to resistance variety where the fruit color was more deep green (Supplementary Figure 1(b)). The adaxial side of leaflet was deep green in resistant variety as compared to susceptible variety where the adaxial leaflet color was pale green (Supplementary Figure 1(d)). The leaflet color in the abaxial side in both varieties was the same and it was pale green (Supplementary Figure 1(c)).

\subsection{Plant Parts Which Were Prone to Aphid Population Establishment}

Aphid colony establishment was not found in all the plant parts of the Dolichos lablab L. Some of plant parts were highly susceptible for aphid population establishment like vine (Supplementary Figure 2(a), Supplementary Figure 2(b)), leaf petiole (Supplementary Figure 2(d)), leaflet veins (Supplementary Figure $2(c)$ ), immature fruit, flower etc. So it was better approach to monitor the differential aphid population establishment in those susceptible targets for better understanding of plant defense response.

\subsection{Differential Response to Aphid Colony Establishment in Vines}

The aphid infested vines from both the varieties were randomly selected at the early aphid infestation stage. This initiation stage was chosen because both "antibiosis" and "antixenosis" were effective and both the mechanisms gave lower number of aphid counts. The "antibiosis" mechanism is functional when the aphid metabolic activity is modulated by the plant defense response and ultimately affects on aphid fecundity. Another mechanism is "antixenosis" that strongly gives non-preference and plant does not act as an excellent host plant. During the early infestation, aphid will search alternative host if aphid faces extreme "antixenosis" from the present plant. This aphid population difference is significantly prominent in the early period of aphid infestation time (Figure 1). The $30 \mathrm{~cm}$ vine length from the tip of the vine is considered for aphid counting. It is observed that total number of aphids were significantly different in both the 
genotypes $(\mathrm{p}=0.00)$. Based on aphid number (Figure 1(a)), the genotypes were classified as "resistant" as well as "susceptible" variety. The result shows that total aphid count was $215.5 \pm 16.9$ in susceptible variety, where as the aphid number in resistant variety at the same time was $48.2 \pm 2.2$. The mean number of aphids in both the genotypes were highly significant $(\mathrm{p}=0.00)$. The same data is further analyzed in such a way that the number of aphids is considered below the mean number $(215 \pm 16.9)$ in the susceptible variety and the number of aphids is considered above the mean number $(48 \pm 2.2)$ in the resistant variety. After analysis, a significant difference was found in mean number of aphids in both the genotypes $(\mathrm{p}=0.00)$. The mean aphid number in susceptible variety was $134 \pm 6.5$ and in resistant variety: $58 \pm 3.6$ (Figure $1(\mathrm{~b})$ ).

\subsection{Plant Specific Factors That Modulate Aphid Colony Proliferation}

\subsubsection{Vine Diameter}

Characteristically, it was recorded that the average vine diameter of susceptible variety was significantly higher as compared to resistant variety ( $\mathrm{p}$ value $=0.00$, Figure 2(a)). The average diameter of susceptible vine was $2.29 \pm 0.094 \mathrm{~mm}$ where as the average diameter of resistant vine was $1.22 \pm 0.047 \mathrm{~mm}$. Due to increase in vine diameter, the distance from epidermis to the phloem cell was also higher (data not shown). The stylet length of a particular aphid is the characteristic feature of that aphid species. The fitness of aphid stylet length to reach into the phloem may be optimum for sucking the sieve element sap from phloem tissue in the higher diameter vine. Another significant observation was that the intercellular space between mesophyll cells was also higher in higher diameter vine. Aphid can explore the intercellular space during stylet penetration to avoid

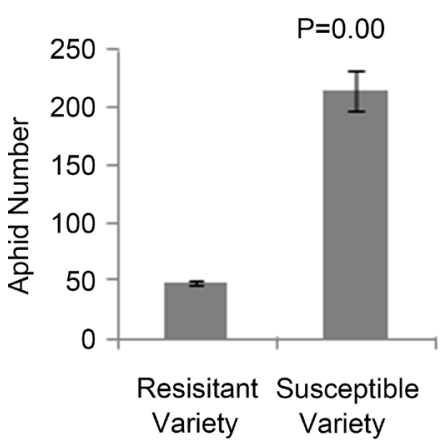

(a)

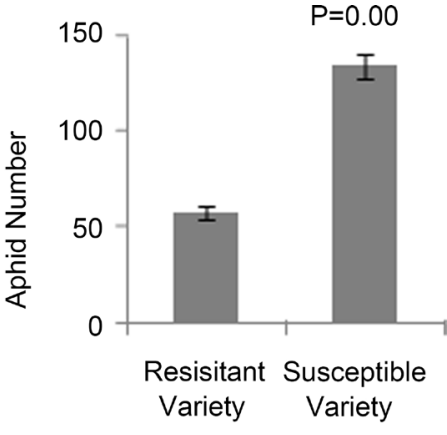

(b)

Figure 1. Differential Genotypic response to aphid colony establishment in both vines. The aphid colony establishment in vine was measured in term of aphid number. (a) The differential aphid colony establishment was found on both the vine (total length considered is $30 \mathrm{~cm}$ from the tip of vine). The result shows that total aphid numbers are 215.5 \pm 16.9 where as the aphid numbers in resistant variety are $48.2 \pm 2.2$. The mean numbers of aphid in both genotypes are highly significant $(\mathrm{p}=0.00)$. (b) The aphid numbers above the mean value, $48.2 \pm 2.2$ in resistant variety and below the mean aphid numbers, 215.5 \pm 16.9 in the susceptible variety were considered for further calculation. The selective data again shows that significant difference in aphid numbers in both genotypes realized (mean value in susceptible variety-58 \pm 3.6 and resistant variety-134 $\pm 6.5, \mathrm{p}=0.00$ ). 
the cell rupture because the stylet penetration of aphid is intercellular that bypasses the plant defense response to sucking insect [8]. It was also observed that the phloem area as well as sieve element cell volume were also increased due to more vine diameter (data not shown). This higher diameter specifically facilitates and have promoting role in sieve element sap ingestion, which gives more proliferation in aphid population.

\subsubsection{Wet/Dry Weight Ratio of Vine}

Characteristically it was found that the ratio of wet weight by dry weight was higher in susceptible vines as compared to resistant vines ( $\mathrm{p}$ value $=0.00$, Figure $2(b))$. This parameter indicated that susceptible vines had more water portion as compared to resistant vine. Anatomically, the plant vine is composed of various types of cell including epidermis and endodermis. The vascular system like xylem and phloem is the characteristic feature of the higher plants in both monocots and dicots. The phloem functions as a resource distribution and signaling conduit and the xylem functions as water as well as mineral translocator from root to shoot. More watery portion in susceptible vine indicates more sap in the vascular system and aphid are more assured to tap the phloem sap continuously. This higher feeding promotes aphid proliferation in the vine.

\subsubsection{The Vine Growth Rate}

Aphid population density was higher in susceptible vines as compared to resistant vines (Figure 1(a)), where as the growth rate was significantly higher in susceptible vine as compared to resistant vine (Figure 2(c)). The vine growth in 3 days was $13.74 \pm 0.84 \mathrm{~cm}$ and growth rate was $4.6 \pm 0.28 \mathrm{~cm} /$ day in resistant variety where as the vine growth in 3 days was $23.69 \pm 1.45 \mathrm{~cm}$ and growth rate was $7.9 \pm 0.48 \mathrm{~cm} /$ day in susceptible variety. The growth rate of vine in susceptible variety as compared to resistant variety was 1.725 times more in a day. So the actual mean number of aphids in susceptible variety was higher than the mean aphid numbers $(215.5 \pm 16.9)$ in the susceptible variety.

\subsubsection{Phloem Sap Pressure in Both Varieties}

Another interesting feature of phloem is that phloem sap is maintained with high pressure. One mode of tapping phloem sap is the passive mode and this mode is explored to suck the sap due to higher pressure maintained in phloem tissue. After establishing the stylet penetration with the action of both gel and watery saliva, aphid may enjoy the passive drinking. For measurement of the high pressure, the total ooze out sap from vine was collected and measured. The total volume of ooze out per $\mathrm{mm}^{2}$ was indicator for pressure existing in the vascular system. The more ooze out volume per $\mathrm{mm}^{2}$ would indicate more pressure being maintained in the vascular system. The data showed that the ooze out volume in susceptible variety was $0.68 \pm 0.11 \mu \mathrm{l}$ per $\mathrm{mm}^{2}$ where as the ooze out volume in resistant vine is $0.19 \pm 0.10$ (Figure $3(\mathrm{a})$ ). The ooze out volume per $\mathrm{mm}^{2}$ in susceptible variety was 3.6 times the pressure maintained in the resistant variety vine. This data indicated that higher pressure was maintained in susceptible 


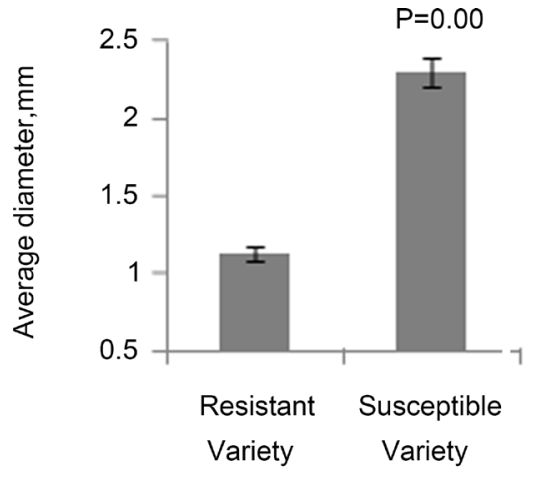

(a)

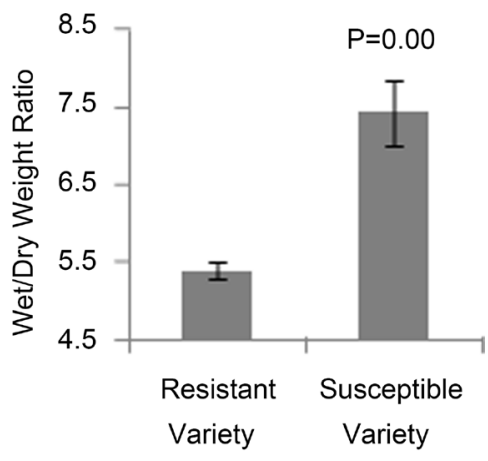

(b)

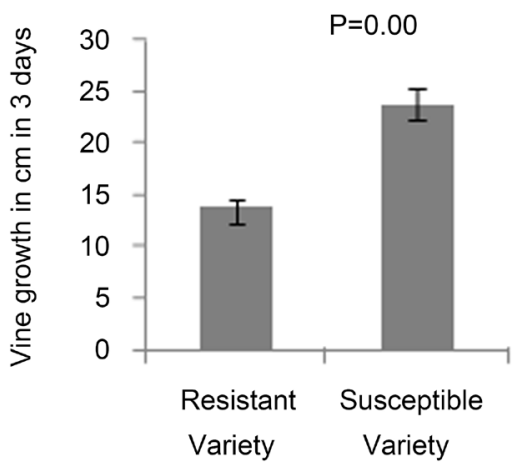

(c)

Figure 2. Plant vine characteristics of both resistant as well as susceptible varieties. (a) Average diameter of vines of both genotypes. The average diameter of three positions (5, $15,25 \mathrm{~cm}$ from the tip of the vine) of the $30 \mathrm{~cm}$ length vine were considered for calculation. (b) Wet/dry weight ratio of $30 \mathrm{~cm}$ vine. (c) Growth rate of both resistant and susceptible varieties in 3 days. The growth rate @ $4.6 \pm 0.28 \mathrm{~cm} /$ day in resistant variety and $@ 7.9 \pm 0.48 \mathrm{~cm} /$ day in susceptible variety were recorded.

variety in the vascular system (Figure 3(a)) and the aphid explored this higher pressure for passive ingestion and maintained well feeding.

\subsubsection{Vine Compactness Measurement}

The average pressures to penetrate the metallic probe to $0.8 \mathrm{~mm}$ of three points $(5,15.25 \mathrm{~cm}$ from the tip of vine) were considered for calculation. The maximum pressure required for penetrating $0.8 \mathrm{~mm}$ was $69.07 \pm 2.29 \mathrm{~g}$ (Figure 4) in resistant vine where as the maximum pressure required for penetrating $0.8 \mathrm{~mm}$ was $63.43 \pm 1.49 \mathrm{~g}$ (Figure 4). Aphid penetrates its slender stylet towards the sieve element. The toughness was higher in resistant variety vines as compared to susceptible vines ( $p=0.0361$, Figure 4 ). It is easier to penetrate the slender stylet in susceptible vines. The toughness was also significantly higher in different parts of intra-vines of both genotypes as well as inter-vines (Supplementary Figure 3(a) and Supplementary Figure 3(b)).

\subsection{Impact of Some Characteristic Features on Overall Aphid Number in Both Genotypes}

It was found that some plant specific features promoted the aphid number in susceptible genotype. Aphid did not colonize the entire plant, rather specific 


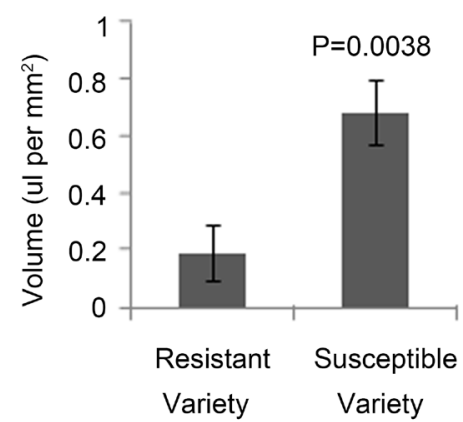

(a)

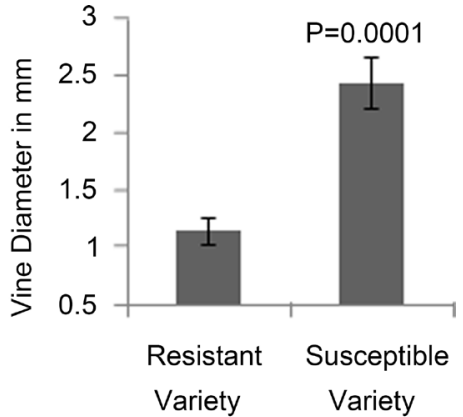

(b)

Figure 3. Phloem sap pressure in both varieties. (a) Sap Ooze-out volume per $\mathrm{mm}^{2}$ (in $15 \mathrm{~s})$. The ooze out volume coming from vine in susceptible variety is $0.68 \pm 0.11 \mu \mathrm{l}$ per $\mathrm{mm}^{2}$ where as the ooze out volume coming from vine in resistant variety is $0.19 \pm 0.10$. The ooze out volume per $\mathrm{mm}^{2}$ in susceptible variety was 3.6 times more than the resistant variety vine. (b) Vine diameter in $\mathrm{mm}$. The vines considered for sap ooze-out volume were also considered for diameter measurement. The data indicated that vines from both the genotypes were significantly different $(p=0.0001)$.

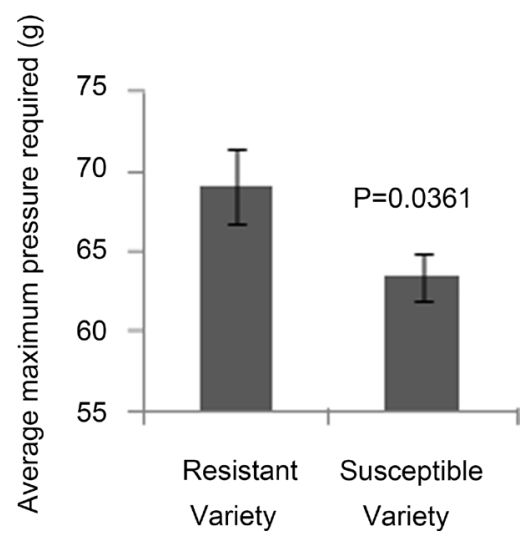

Figure 4. The maximum pressure required to penetrate $0.8 \mathrm{~mm}$ of the pointed probe under constant pressure $(5 \mathrm{~g})$. Average maximum pressure required to penetrate the pointed probe in both vines of susceptible as well as resistant varieties. The $\mathrm{p}$ value indicates the significant difference for the maximum pressure required.

parts like vine, leaf petiole, leaflet veins at the base portion, inflorescence, immature fruits etc. (Supplementary Figure 2). The same sized leaflet (Figure 5(b)) was fleshier as compared to resistant variety leaflet (Figure 5(a), p = 0.0255). This also ensured more aphid proliferation in this leaf and affected accumulative aphid number in the plant. From the leaflet wilting experiment, it was found that the turgor pressure was more in susceptible leaflet as compared to resistant leaflet (Figure 5(c)). In this experiment, leaflet of same size (Figure 5(b)) were collected and kept on $2 \mathrm{ml}$ centrifuge tube for 10 minutes without water or any solution. Within the susceptible genotype, the variation of leaflet size also existed. On consideration of larger sized leaflet, it was found that the ratio of wet/dry weight was also significantly higher (Supplementary Figure 4 (a) and $\mathrm{p}=0.0001$ ) and had the significant difference in diameter at the base of the respective leaflet (Supplementary Figure $4(\mathrm{~b})$ and $p=0.00$ ), that promoted aphid colony proliferation. Further fine tuning of the larger sized leaflet, it was 


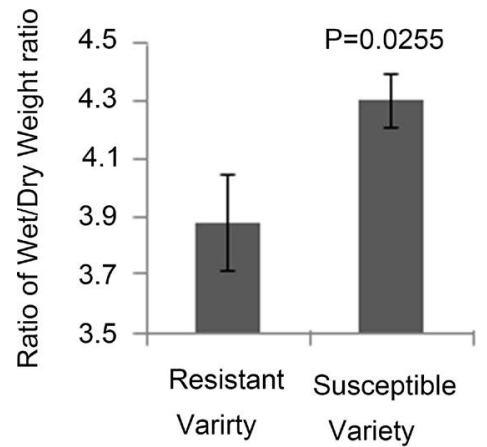

(a)

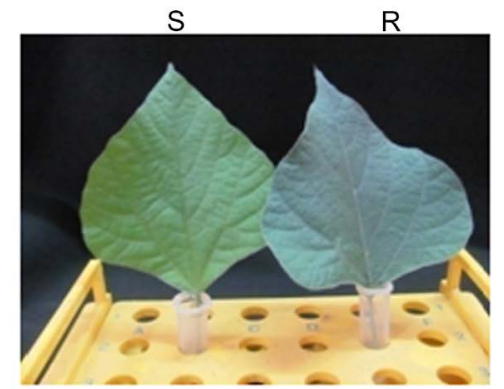

(c)

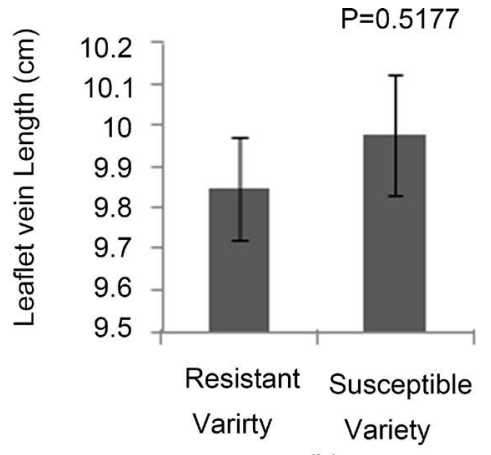

(b)

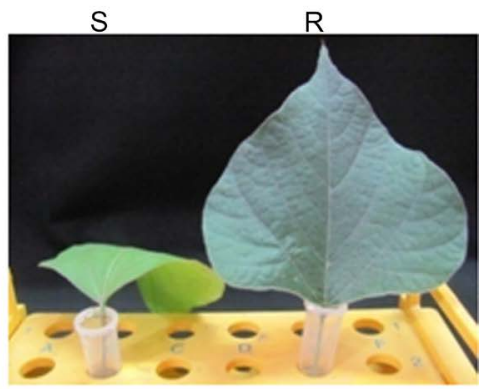

(c)

Figure 5. Some characteristic features which had an impact on aphid number variation in both the genotypes. (a) Ratio of Wet/Dry Weight in medium size leaflet. (b) Leaflet vein Length $(\mathrm{cm})$. (c) Leaflet drooping experiment shows that susceptible leaflet was more to wilt as compared to resistant leaflet.

found that the relative distribution of aphid colony proliferation within larger size leaflet was also significantly different (Supplementary Figure $4(\mathrm{c})$ and $\mathrm{p}=$ 0.0001) and it was correlated with the diameter of the leaflet vein diameter (Supplementary Figure 4(d) and $p=0.0001$ ).

\subsection{Plant Specific Factors That Had an Impact on Aphid Specific Parameter}

The argument may arise that significantly higher number of aphids in susceptible vine was due to initial inoculums, not from the true proliferation. Aphid generally does not move from one plant to another plant but the alate form moves from one plant to another but it would be produced in particular environment. To address the argument, initial infestation phase was chosen when there was no competition of space among aphids for getting enough phloem sap. The immature to mature stages was chosen for fecundity count. If the aphid was well fed, it showed high fecundity, otherwise it showed lower fecundity. In the resistant vine, the ratio of instars $1-4$ to instars 5 i.e. immature aphid to adult aphid was significantly lower than the susceptible vine (Figure 6(a)). The mean number of progenies per adult was $0.89 \pm 0.12$ in resistant vine whereas the mean number of progenies per adult was $2.68 \pm 0.35$ in susceptible vine (Figure $6(\mathrm{a})$ and $\mathrm{p}=0.00)$. Moreover, the wet/dry weight ratio of aphids collected from vine was also significantly higher (Figure $6(\mathrm{~b}), \mathrm{p}=0.0378$ ) in susceptible vine (mean value $=2.646 \pm 0.037)$ as compared to resistant vine (mean value $=$ 


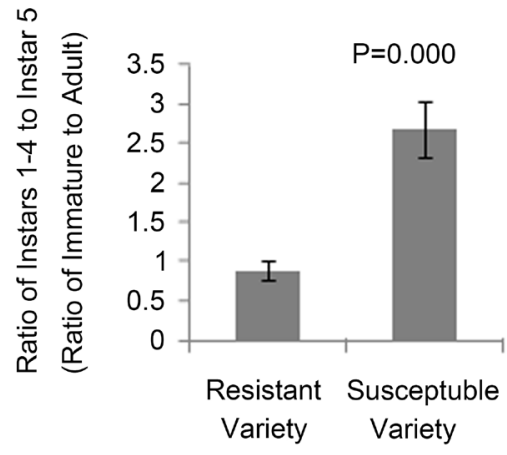

(a)

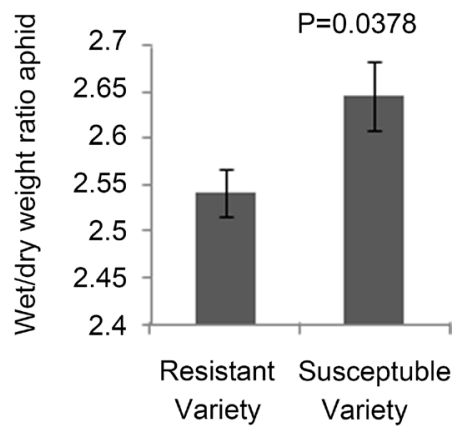

(b)

Figure 6. Aphid characteristics grown in both Resistant as well as Susceptible variety. (a) The ratio of aphid stages belong to Instars $1-4$ to Instars 5 (Immature aphid per adult aphid). The mean number of progenies per adult aphid is $0.89 \pm 0.12$ in resistant vine (30 $\mathrm{cm}$ length from the tip of the vine) where as the mean number of progenies per adult aphid is $2.68 \pm 0.35$ in susceptible vine. (b) The wet weight to dry weight ratio of aphid grown both in resistant and susceptible varieties. The wet/dry weight ratio of aphids collected from vine is also significantly higher $(\mathrm{p}=0.0378)$ in susceptible vine grown aphid (mean value $=2.646 \pm 0.037$ ) as compared to resistant vine grown aphid (mean value $=$ $2.5411 \pm 0.026)$.

$2.5411 \pm 0.026)$. The higher watery portion in aphid was indicative of well feeding of sieve element sap from the susceptible vine as compared to resistant vine. The well feeding promotes more aphid proliferation in susceptible vine and results in higher fecundity.

The results discussed above indicated that aphid proliferation was significantly higher in susceptible vine. Higher aphid population may arise due to more initial harboring of aphid on susceptible vine. But the aphid (entomologically belonging to nymph stage), rarely moved to another plant when isolation distance is more than 4 meters. Moreover, aphids were well fed in susceptible vine as compared to resistant vine because the more water content in aphid was found in susceptible vine. The more phloem sap ingestion may promote more aphid proliferation in susceptible vine as compared to resistant vine and ultimately contribute more progenies per adult aphid in susceptible vine. Aphid facing lesser water content in resistant vine, definitely faces limitation to ingest sufficient volume of phloem sap and/or there was antibiotic effect of phloem sap that discourages aphid fecundity. Some botanic factors like higher diameter, more water content of vine and leaflet, higher turgor pressure in the vascular system, and less compactness of vine in the susceptible variety ensured positively assured well feeding by aphid and more water content ensured more aphid fecundity. The accumulative and/or synergistic effect in susceptible vine derived facilitations, aphid proliferated at a faster rate and ultimately gave more aphid number in the susceptible vine.

\section{Material and Methods}

\subsection{Plant Material Related Information}

Dolichos lablab genotype which was collected from Beldanga, Murshidabad, West Bengal, India was the "susceptible" variety. Another Dolichos lablab geno- 
type collected from Pundibari, Cooch Behar, North West Bengal, India was the "resistant" one.

\subsection{Plant Growth Management}

Both the varieties were sown on October 15, 2015 in Terai zone, Pundibari, Cooch Behar, West Bengal, India. The plant growth was maintained in Terai zone (Pundibari, Cooch Behar) in the UBKV campus. The plant canopy was maintained in iron structure and the dimension of the iron structure was $2.4 \mathrm{~m}$ $\times 1.84 \mathrm{~m} \times 0.8 \mathrm{~m}$ (Length $\times$ Breath $\times$ Height). Irrigation is given as required. No fertilizer was given.

\subsection{Weather Information}

The experimental plot belonged to the "Terai" zone that is positioned in south of the outer Himalayan foothills. The average rainfall in the month of October, November and December was $1.49 \pm 1.02,0.46 \pm 0.39$ and $0.17 \pm 0.12 \mathrm{~mm}$, respectively. The maximum and minimum temperature realized was $32.19^{\circ} \mathrm{C} \pm 0.28^{\circ} \mathrm{C}$ and $20.45^{\circ} \mathrm{C} \pm 0.38^{\circ} \mathrm{C}$ in October $2015,29.13^{\circ} \mathrm{C} \pm 0.23^{\circ} \mathrm{C}$ and $15.27^{\circ} \mathrm{C} \pm 0.40^{\circ} \mathrm{C}$ in November 2015 , and $25.03^{\circ} \mathrm{C} \pm 0.33^{\circ} \mathrm{C}$ and $10.45^{\circ} \mathrm{C} \pm 0.62^{\circ} \mathrm{C}$ in December 2015 . The maximum and minimum relative humidity $(\mathrm{RH})$ was $80.55^{\circ} \mathrm{C} \pm 1.02^{\circ} \mathrm{C}$ and $74.39^{\circ} \mathrm{C} \pm 1.57^{\circ} \mathrm{C}$ in October $2015,82.43^{\circ} \mathrm{C} \pm 1.23^{\circ} \mathrm{C}$ and $83.77^{\circ} \mathrm{C} \pm 0.90^{\circ} \mathrm{C}$ in November 2015 and $89.84^{\circ} \mathrm{C} \pm 0.93^{\circ} \mathrm{C}$ and $85.23^{\circ} \mathrm{C} \pm 1.02^{\circ} \mathrm{C}$ in December 2015.

\subsection{Soil Information}

Soil of the Terai region is mostly acidic in reaction and contains high amounts of $\mathrm{Fe}$ and $\mathrm{Al}$ oxides and hydroxides. Soils of the Pundibari experimental plots were slightly acidic ( $\mathrm{pH} 5.5$ to 6.4 ) and sandy loam in texture with low status of the available $\mathrm{N}, \mathrm{P}_{2} \mathrm{O}_{5}$, and $\mathrm{K}_{2} \mathrm{O}(211,11.4$, and $95 \mathrm{~kg} / \mathrm{ha}$, respectively [22]. The content of $\mathrm{S}(33.7 \mathrm{~kg} / \mathrm{ha})$ and $\mathrm{Zn}(1.25 \mathrm{~kg} / \mathrm{ha})$ was quite high in terms of the critical limit, while extractable B $(0.28 \mathrm{~kg} / \mathrm{ha})$ was low in these experimental soils.

\subsection{Insect}

The plant canopy was maintained under natural environment in terai zone. No protection measure was followed for controlling aphid infestation. Aphid infestation occurred naturally and data was taken at the early infestation stage. When the aphid infestation occurred naturally, data was taken at the early infestation stage. The aphid data was taken at 52 days old plant.

\subsection{Diameter Measurement}

Digimatic Caliper (Mitutoyo Corporation) was used for measuring the diameter of the plant vine in absolute mode i.e. in mm.

\subsubsection{Dry Weight and Wet Weight Measurement}

A vine of length $30 \mathrm{~cm}$ was considered for taking the fresh weight after immediate collection. After taking the total weight data, the vine was incubated at 
$72^{\circ} \mathrm{C}$ for 3 days for drying. After drying, the dry weight was measured. The wet weight was calculated by subtracting dry weight from fresh weight. The wet weight and dry weight ratio was considered for further scientific explanation.

\subsubsection{Turgor Pressure Measurement}

The turgor pressure was measured in terms of phloem sap volume per unit area. The vine was cut at $15 \mathrm{~cm}$ from the tip and allowed for 15 seconds to measure the ooze out volume which was accumulated due to high pressure maintained in phloem. The ooze out volume measurement was taken with the help of $10 \mu \mathrm{l}$ pipette. The volume per unit area of vine was considered for this study. The data was taken at $2 \mathrm{pm}$.

\subsection{Vine Growth Rate of Both Resistant and Susceptible Varieties in 3 Days}

The vine WAS marked at $30 \mathrm{~cm}$ position from the tip of the respective varieties. After 3 days, the total vine length WAS again measured. The vine length increment per day was considered for scientific explanation.

\subsection{Probe Penetration Experiment}

The probe penetration experiment was performed by the TA.XT plus Texture Analyser (Stable Micro Systems). Aphid penetrated its slender stylet into vine to reach into phloem region to tap the nutrient enriched sap. During probe penetration, aphid has to overcome the tissue resistance from plant vine. The probe penetration experiment was performed to measure the resistance of both plant vines. Both vines were in different diameter and the penetration length was considered to be $0.8 \mathrm{~mm}$. During probe penetration, the resistance faced by probe was measured with constant pressure of $5 \mathrm{~g}$. The probe considered for penetration experiment was $2 \mathrm{~mm}$ pointed needle. The resistance was measured in different parts of vines at 5, 15, and $25 \mathrm{~cm}$ from the tip of the vine. The average pressures of three points of both vines were considered for calculation.

\subsection{Statistical Analysis}

All the statistical calculation was performed by using the Minitab 15 Statistical Software. Comparison between two sets of data was carried out by General Linear Model.

\section{Acknowledgements}

The authors are thankful to the Head, Department of Genetics and Plant Breeding, UBKV for providing all the infrastructural help. The authors are also thankful to Central Instrumentation Centre (CIC), UBKV for taking Probe penetration experiment and providing access to instrument for taking weight data. The authors are thankful to "Gramin Krishi Mousam Sewa (IAAS)" for providing the weather data. The technical assistance from technical person from CIC, $\mathrm{UBKV}$ is sincerely acknowledged. 


\section{References}

[1] Valenzuela, H. and Smith, J. (2002) Sustainable Agriculture Green Manure Crops. SA-GM-7. Cooperative Extension Service, College of Tropical Agriculure and $\mathrm{Hu}-$ man Resources, University of Hawaii at Manoa.

[2] Cook, B.G., Pengelly, B.C., Brown, S.D., Donnelly, J.L., Eagles, D.A., Franco, M.A., Hanson, J., Mullen, B.F., Partridge, I.J., Peters, M. and Schultze-Kraft, R. (2005) Tropical Forages: An Interactive Selection Tool. Lablab purpureus. CSIRO, DPI\&F (Qld), CIAT, and ILRI, Brisbane, Australia.

[3] Stevens, J.M. (2012) Bean, Hyacinth-Dolichos lablab L., or Lablab purpureus (L.) Sweet. Publication \#HS552. Institute of Food and Agricultural Sciences (IFAS), University of Florida Extension.

[4] Anderson, R.G., Bale, S. and Jia, W. (1996) Hyacinth Bean: Stems for the Cut Flower Market. In: Janick, J. and Simon, J.E., Eds., Progress in New Crops, ASHS Press, Arlington, 540-542.

[5] Murphy, A.M. and Colucci, P.E. (1999) A Tropical Forage Solution to Poor Quality Ruminant Diets: A Review of Lablab purpureus. Livestock Research for Rural Development, 11, 96-113.

[6] Maass, B.L., Knox, M.R., Venkatesha, S.C., Angessa, T.T., Ramme, S. and Pengelly, B.C. (2010) Lablab purpureus-A Crop Lost for Africa? Tropical Plant Biology, 3, 123-135. https://doi.org/10.1007/s12042-010-9046-1

[7] Blackman, R.L. and Eastop, V.F. (2000) Aphids on the World's Crops. John Wiley and Sons, Chichester.

[8] Tjallingii, W.F. (1990) Continuous Recording of Stylet Penetration Activities by Aphids. In: Campbell, R.K. and Eikenbary, R.D., Eds., Aphid-Plant Genotype Interactions, Elsevier, Amsterdam, 89-99.

[9] Mutti, N.S., Louis, J., Pappan, L.K., Pappan, K., Begum, K., Chen, M.S., et al. (2008) A Protein from the Salivary Glands of the Pea Aphid, Acyrthosiphon pisum, Is Essential in Feeding on a Host Plant. Proceedings of the National Academy of Sciences of the United States of America, 105, 9965-9969.

https://doi.org/10.1073/pnas.0708958105

[10] De Vos, M. and Jander, G. (2009) Myzus persicae (Green Peach Aphid) Salivary Components Induce Defence Responses in Arabidopsis thaliana. Plant, Cell \& Environment, 32, 1548-1560. https://doi.org/10.1111/j.1365-3040.2009.02019.x

[11] Miles, P.W. (1999) Aphid Saliva. Biological Reviews, 74, 41-85.

[12] Cherqui, A. and Tjallingii, W.F. (2000) Salivary Proteins of Aphids, a Pilot Study on Identification, Separation, and Immunolocalisation. Journal of Insect Physiology, 46, 1177-1186.

[13] Powell, G. (2005) Intracellular Salivation Is the Aphid Activity Associated with Inoculation of Non-Persistently Transmitted Viruses. Journal of General Virology, 86, 469-472. https://doi.org/10.1099/vir.0.80632-0

[14] Campbell, B.C. and Dreyer, D.L. (1990) The Role of Plant Matrix Polysaccharides in Aphid-Plant Interactions. In: Campbell, R.K. and Eikenbary, R.D., Eds., Aphid-Plant Genotype Interactions, Elsevier, Amsterdam, 149-169.

[15] Miles, P.W. and Oertli, J.J. (1993) The Significance of Antioxidants in the Aphid-Plant Interaction: The Redox Hypothesis. Entomologia Experimentalis et Applicata, 67, 273-285. https://doi.org/10.1111/j.1570-7458.1993.tb01678.x

[16] Gould, N., Minchin, P.E.H. and Thorpe, M.R. (2004) Direct Measurements of Sieve Element Hydrostatic Pressure Reveal Strong Regulation after Pathway Blockage. 
Functional Plant Biology, 31, 987-993. https://doi.org/10.1071/FP04058

[17] Schulz, A. (1998) The Phloem Structure Related to Function. In: Behnke, H.-D., Esser, K., Kadereit, J.W., Lüttge, U. and Runge, M., Eds., Progress in Botany, Springer, Berlin Heidelberg, 429-475. https://doi.org/10.1007/978-3-642-80446-5_16

[18] Knoblauch, M. and van Bel, A.J.E. (1998) Sieve Tubes Inaction. The Plant Cell, 10, 35-50. https://doi.org/10.1105/tpc.10.1.35

[19] Cronshaw, J. (1981) Phloem Structure and Function. Annual Review of Plant Physiology, 32, 465-484. https://doi.org/10.1146/annurev.pp.32.060181.002341

[20] Cronshaw, J. and Sabnis, D.D. (1990) Phloem Proteins. In: Behnke, H.D. and Sjolund, R.D., Eds., Sieve Elements. Comparative Structure, Induction, and Development, Springer-Verlag, Berlin, 257-283.

[21] Furch, A.C.U., Hafke, J.B., Schulz, A. and van Bel, A.J.E. (2007) $\mathrm{Ca}^{2+}$-Mediated Remote Control of Reversible Sieve Tube Occlusion in Vicia faba. Journal of Experimental Botany, 58, 2827-2838. https://doi.org/10.1093/jxb/erm143

[22] Mukhopadhyay, D., Majumdar, K., Pati, R. and Mandal, M.K. (2008) Response of Rainfed Rice to Soil Test-Based Nutrient Application in Terai Alluvial Soils. Better Crops, 92, 13-15. 


\section{Appendix}

Supplementary Figure (SF). 1. The characteristic features of flower and fruit in both varieties (R-Resistance, S-Susceptible).

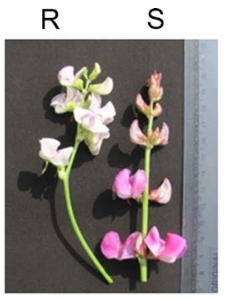

(a)

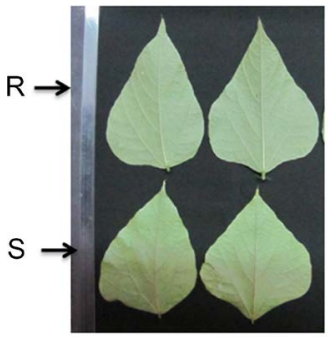

(c) Abaxial side of leaf

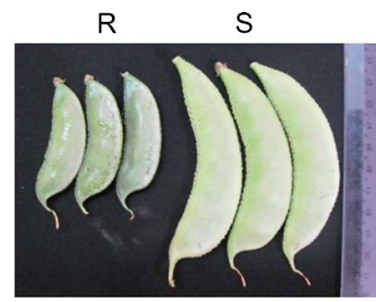

(b)

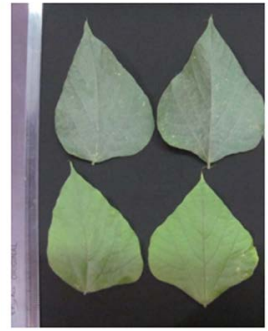

(d) Adaxial side of leaf

Supplementary Figure 1. (a) The difference in petal color in the both varieties. The Left one is Resistant variety flower and the right one is Susceptible variety flower. (b) The fruit characteristic of both the varieties. The fruit size of susceptible variety was higher than resistant variety. (c) The abaxial side of leaf in both the varieties were pale green in color. (d) The adaxial side of leaf in both varieties but the leaf color in resistant variety was deep green.

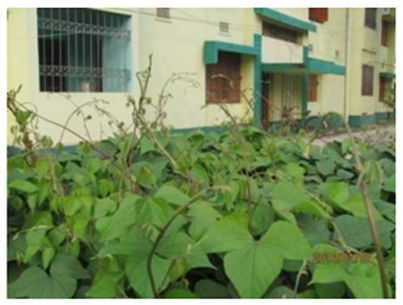

(a)

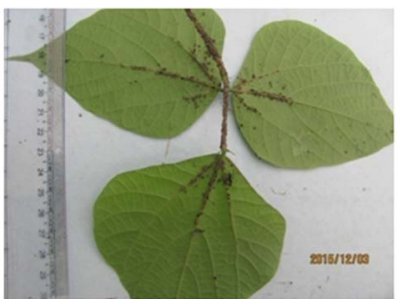

(c)

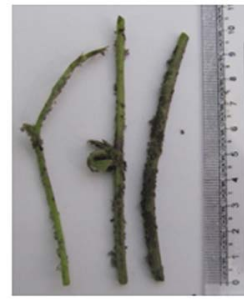

(b)

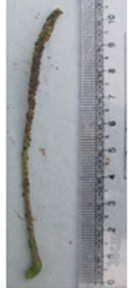

(d)

Supplementary Figure 2. Plant parts prone to aphid population establishment. (All aphid infested plant parts are taken from susceptible genotype). (a) The canopy of susceptible genotype maintained in iron structure. (b) The vine of $30 \mathrm{~cm}$ is highly susceptible for aphid colony establishment. Within figure, the left vine is $10 \mathrm{~cm}$ from tip of the vine, middle is next $10 \mathrm{~cm}$ from the $1^{\text {st }}$ vine, and right one is $10 \mathrm{~cm}$ vine from $2^{\text {nd }}$ vine. On all parts of vine aphid population was established. (c) The leaf veins but at the base of the leaflets are prone to aphid population establishment. (d) The leaf petiole is another target for aphid population establishment. 


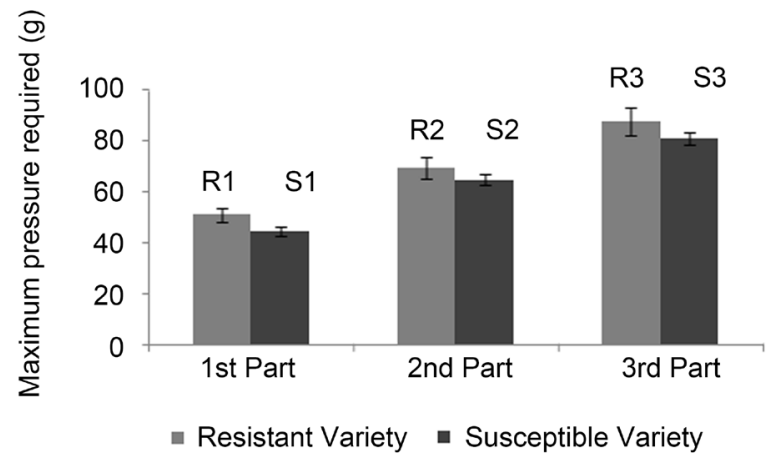

(a)

\begin{tabular}{|c|c|c|c|c|c|c|}
\hline & R1 & R2 & R3 & S1 & S2 & S3 \\
\hline R1 & & 0.0069 & 0 & 0.8062 & 0.0958 & 0 \\
\hline R2 & & & 0.0103 & 0.0001 & 0.9116 & 0.2239 \\
\hline R3 & & & & 0 & 0.0005 & 0.7902 \\
\hline S1 & & & & & 0.0033 & 0 \\
\hline S2 & & & & & & 0.022 \\
\hline
\end{tabular}

(b)

Supplementary Figure 3. (a) Pressure required to penetrate $0.8 \mathrm{~mm}$ in both vines in different points $(5,15,25 \mathrm{~cm}$ from the tip of the respective vines from both genotypes). R1, $\mathrm{R} 2$ and R3 indicate the point of penetration at 5,15 and $25 \mathrm{~cm}$ from the tip of the resistant vine. S1, S2 and S3 R3 indicate the point of penetration at 5, 15 and $25 \mathrm{~cm}$ from the tip of the susceptible vine. (b) The table for $\mathrm{p}$ values.

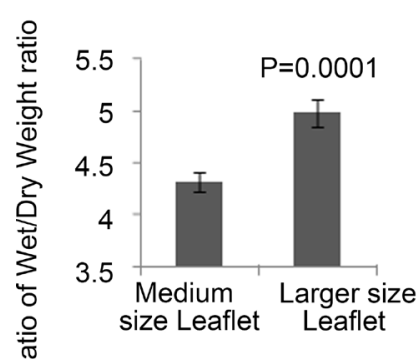

(a)

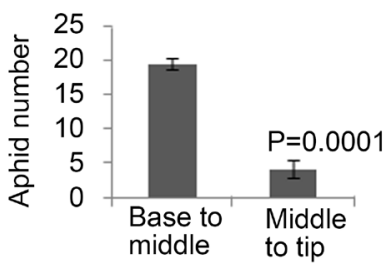

(c)

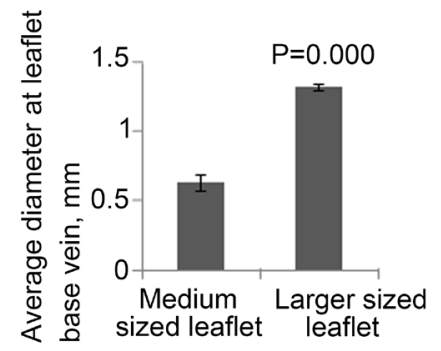

(b)

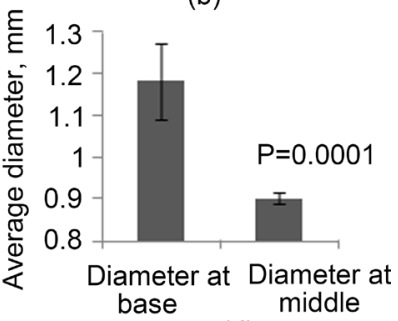

(d)

Supplementary Figure 4. Some parameters that promote aphid number in the susceptible variety. (a) Characteristic feature of medium as well as larger sized leaflet. Ratio of Wet/Dry Weight of medium and larger sized leaflet within Susceptible Variety. (b) The vein diameter in $\mathrm{mm}$ at the base of leaflet in both medium and larger sized leaflets within susceptible variety. This signified that larger sized leaflet within same genotype gives more leaflet diameter at the base. (c) The relative distribution of aphid within different parts of the larger sized leaflet. (d) The diameter at the base as well as middle of the larger sized leaflet. Characteristic feature within the larger sized leaflet. 